\title{
Weisiopsis nigeriana (Pottiaceae, Bryophyta) new to Australia, with perennating rhizoids
}

\author{
Richard H. Zander ${ }^{1, *}$, Philip Sollman² \\ ${ }^{1}$ Missouri Botanical Garden, PO Box 299 St. Louis, Missouri, U.S.A. 63116 \\ ${ }^{2}$ Netarisappel 2, 9076 LB St. Anna Parochie, NLD, The Netherlands \\ "Author for correspondence: richard.zander@mobot.org
}

\begin{abstract}
The widely distributed but rarely collected moss Weisiopsis nigeriana (Egun. \& Olarinmoye) R.H.Zander is reported as new to Australia. The world range is reviewed, and an illustration given. Unique inflated rhizoids of bulging short cells filled with dense protoplasm and oil globules are an apparent mode of survival during dry periods.
\end{abstract}

\section{Introduction}

The moss Weisiopsis nigeriana (Egun. \& Olarinmoye) R.H.Zander (Pottiaceae, Bryophyta) has a scattered distribution across tropical and subtropical areas, occurring on dry soil and rock. Its small size and lack of salient memorable features may contribute to uncommon collecting, but one might also attribute its apparent rarity to the fact that dry areas are seldom sampled by bryologists. This species has been reported for Brazil (Costa 2015; Farias Castro et al. 2002), Central America (Costa Rica, Honduras, Panamá) (Allen 2002), Ivory Coast, Tanzania, and Zambia (O'Shea 2006), and in the original publication from Nigeria (Egunyomi and Olarinmoye 1978). An extensive discussion of the species, with synonymy, has been provided by Allen (2002: 207), who pointed out the distinctive bulging capsule exothecial cells, and provided a good description.

A very large set of especially pottiaceous mosses were sent from the herbarium at Canberra (CBG) to that in Leiden (L) for identification. In all, several thousand numbers largely collected by H. Streimann were named over the years by the second author. The Weisiopsis collections from Australia formed one of the last puzzles. The present paper reports W. nigeriana as new to the moss flora of Australia.

\section{Methods}

Neither Weisiopsis nigeriana nor any other species of this genus has been previously reported for Australia according to Streimann and Klazenga (2002) in their checklist of Australian mosses. Searches of the Web and literature yielded no relevant reports for this species. The herbaria at $\mathrm{MO}$ and $\mathrm{L}$ were consulted as particularly rich in tropical and subtropical Pottiaceae. 


\section{Results}

In Australia, Weisiopsis nigeriana has been collected in rocky gorges, remnant monsoon forests, savanna dominated by large shrubs, and Eucalyptus-dominated grasslands. The material collected (Fig. 1) had both perichaetiate and apparently rhizautoicous separate plants, but lacked sporophytes. During study of this species, it was found to be new to Zimbabwe based on a herbarium collection cited below.

The genus Weisiopsis Broth. includes only seven species, previously found in southern and eastern Asia, Mexico, Central America, Brazil, central and southern Africa, and Madagascar; growing on rocks and soil. This is a report of the first discovery of the genus in Australia, excepting a mention of an unidentified Weisiopsis being drawn for the Moss Flora of Australia (Downing 2011), which is probably this species. According to Zander (1993) the genus has small stature; central strand present; leaves tubulose, long-ligulate to spathulate; leaf margins plane or broadly and weakly incurved, entire or minutely crenulate; leaf apex rounded to broadly acute; costal section nearly round, with one central stereid band round in section, when present guide cells often flattened, lenticular; distal laminal cells rounded-hexagonal to quadrate, bulging strongly adaxially, flat to convex abaxially; basal laminal cells often somewhat enlarged; laminal papillae absent; monoicous; perichaetial leaves little differentiated; peristome absent or teeth 16 , short and straight; laminal $\mathrm{KOH}$ color reaction yellow

Weisiopsis nigeriana, illustrated from the non-fruiting Australian material (Fig. 1), differs from other species of the genus by the laminal cells bulging on both sides of the lamina, although more strongly on the adaxial side, and has bulging exothecial cells on the capsule, which was, however, not found in Australia. Pending discovery of fruiting material, this is the best placement of this tiny moss. It has the major characteristic of the genus of the distinctive central stereid band in the costa, with one or two layers of epidermal cells. The guide cells are missing. A central stereid band is otherwise rather rare in the Pottiaceae, e.g. as occurs in Scopelophila ligulata (Spruce) Spruce, a species which, however, lacks a stem central strand. It is immediately distinguished from Hyophila involuta (Hook.) A.Jaeger by the short-excurrent costa and relatively large sized leaves of that species.

A small number of collections of Weisiopsis nigeriana have been made in Australia and placed in herbaria without identification to species. Specimens have been named to various genera with obovate leaves, including Gyroweisia and Splachnobryum in addition to Weisiopsis. The Australian specimens, particularly Streimann 39485 (B, L, MO), are particularly important for good expression of a trait distinctive in this species-what are apparently perennating rhizoids (Fig. 1A, 1B). These are similar to the usual rhizoids of W. nigeriana, with slanting cross-walls and branching orthogonal to the cross-walls, but are of short, bulging cells, two to four times as wide to $45-50 \mu \mathrm{m}$, and are filled with dense protoplasm and globular oil bodies. These and the wellrepresentative leafy plants are here illustrated (Fig. 1). The perennating rhizoids were also found in a specimen of the same species from Zambia: Pócs et al. 6622/J (MO), though somewhat less well developed. They were not found in other specimens, and may be a biotype adapted to the hot, dry, tropical Australian climate.

\section{Discussion}

The family Pottiaceae is replete with species apparently adapted to arid or otherwise inhospitable environments (Zander 1993). Occasionally, morphological features are easy to ascribe functional attributes, and these include oil-rich leaves or specialized perennating organs (rhizoid-borne brood bodies) in species found in the driest sites. Scott (1982: 117) pointed out that perennation from rhizoids is rarely reported. Moore and Scott (1979) listed Barbula torquata, Tortella calycina and Tortula princeps with apparent generation from rhizoids. Perennating rhizoids may also be found in other pottiaceous species, probably simply not recognized as a taxonomic feature. Perennating rhizoids were found in Hyophila involuta (Hook.) A.Jaeger (Western Australia, Lillimilora, Kimberly, G. Scott, s.n., 8 May 1988, MO) and also in Quaesticula navicularis (Mitt.) R.H.Zander (Bolivia, Santa Cruz, A. Fuentes 2939, 17 April 2001, MO) that were more straight (less sinuose) and had longer cells than those in Weisiopsis nigeriana, but were of similar width, 30-50 $\mu \mathrm{m}$, and had similarly dense protoplasm that, at least in fresh material, contained large, round oil globules.

\section{Specimens of Weisiopsis nigeriana examined}

BRAZIL. Piauí, Parque Nactional de Sete Cidades, 22 km de Piripiri along BR-222/343, rock, 100-300 m, Farias Castro 16, 25 October 1995 (MO). COSTA RICA. Puntarenas Prov., near Cascajal, 25 km ESE of Puntarenas, pasture, dry rock, 120 m, R. W. Holm and H. H. Iltis 1325, Jul 1949 (MO). HONDURAS. Comayagua Dept., plains E of Siguatepeque, dry bank, 1050 m, T. G. Yunker et al. 6652, 6 Aug 1936 (MO). PANAMÁ. Veraguas Prov., La Yeguada, soil, R. Mendoza 864, Oct 1977 (MO). 
ZAMBIA. Kundulila Falls SE of Kanona, rocks near falls, 1480 m, T. Pócs et al. 6622/J, 17 Jan 1972 (MO). ZIMBABWE. Clark Farm near Pungwe Falls, wet mountain forest, side of sandstone boulder, R. E. Magill 10162, 28 Mar 1991 (MO).

AUSTRALIA. Queensland, Peninsula Development Road, $14 \mathrm{~km} \mathrm{~N}$ of Musgrave, Bamboo Range, $79 \mathrm{~km}$ SSE of Coen, 240 m, semi-shaded boulder, H. Streimann 56658, 16 Oct 1995 (H, L, MO, NY). Northern Territory, Umbrawarra Gorge, $22 \mathrm{~km} \mathrm{SW}$ of Pine Creek, shaded rock face, $210 \mathrm{~m}$, H. Streimann 48557, 48563, 18 Jul 1991 (CBG); Baroalba Creek, 19 km S of Jabiru, Kakadu National Park, rock outcrop, 70 m, H. Streimann 39538, 25 May 1988 (CBG); Arnhem Land, 19 km ENE of Jabiru airfield, rock face on side of gully, $140 \mathrm{~m}$, H. Streimann 42174, 18 Apr 1989 (CBG). Western Australia, Lake Argyle Road, 35 km SE of Kununurra, SW escarpment, shaded rock face, 140 m, H. Streimann 39485, 22 May 1988 (B, L, MO); 31 km SE of Kununurra, 160 m, shaded rock face, H. Streimann 48341, 8 Jul 1991 (CBG); Kununurra-Timber Creek highway, 25 km SE of Kununurra, 100 m, semi-exposed rock face, H. Streimann 48369, 9 Jul 1991 (CBG); Gibb River Road, 45 km SSE of Wyndham, semi-exposed rock face, 140 m, H. Streimann 48514, 16 Jul 1991 (CBG).

\section{Acknowledgments}

The Missouri Botanical Garden is thanked for its continued support for bryophyte research. The illustration, contributed by Patricia M. Eckel, Missouri Botanical Garden, is much appreciated. We acknowledge the aid of Dr. Niels Klazenga, Royal Botanical Gardens, Melbourne, for information on the Australian bryoflora.

\section{References}

Allen B (2002) Moss flora of Central America. Part 2. Encalyptaceae-Orthotrichaceae. (Missouri Botanical Garden: St. Louis)

Costa DP, Peralta DF (2015) Bryophyte diversity in Brazil. Rodriguésia 66: 1063-1071. https://doi. org/10.1590/2175-7860201566409

Downing, A. 2011. Scientific illustration and bryophytes at the International Botanical Congress, Melbourne 2011. Austalasian Systematic Botany Society Newsletter 149: 29-30.

Egunyomi A, Olarinmoye SO (1978) A new species of Gyroweisia (Musci: Pottiaceae) from Nigeria. Bryologist 81: 443-445. https://doi.org/10.2307/3242251

Farias Castro NMC, Calcanti Pôrto K, Yano O, Farias Castro, AAJ (2002) Levantamento florístico de Bryopsida de Cerrado e Mata Ripícola do Parque National de Sete Cidades, Paiuí, Brasil. Acta Botanica Brasilica 16: 61-76. https://doi.org/10.1590/S0102-33062002000100008

Moore CJ, Scott GAM (1979) The ecology of mosses on a sand dune in Victoria, Australia. Journal of Bryology 10: 291-311. https://doi.org/10.1179/jbr.1979.10.3.291

O'Shea BJ (2006) Checklist of the mosses of sub-Saharan Africa (version 5, 12/06). Tropical Bryology Research Reports 6: 1-252.

Scott GAM (1982) Desert bryophytes. Pp. 105-122 in: Smith AJE. Bryophyte Ecology. (Chapman and Hall: London) https://doi.org/10.1007/978-94-009-5891-3_4

Streimann H, Klazenga N (2002) Catalogue of Australian mosses. Flora of Australia Supplementary Series 17. (Australian Biological Resources Study, Canberra)

Zander RH (1993) Genera of the Pottiaceae, mosses of harsh environments. Bulletin of the Buffalo Society of Natural Sciences 32: 1-378. 


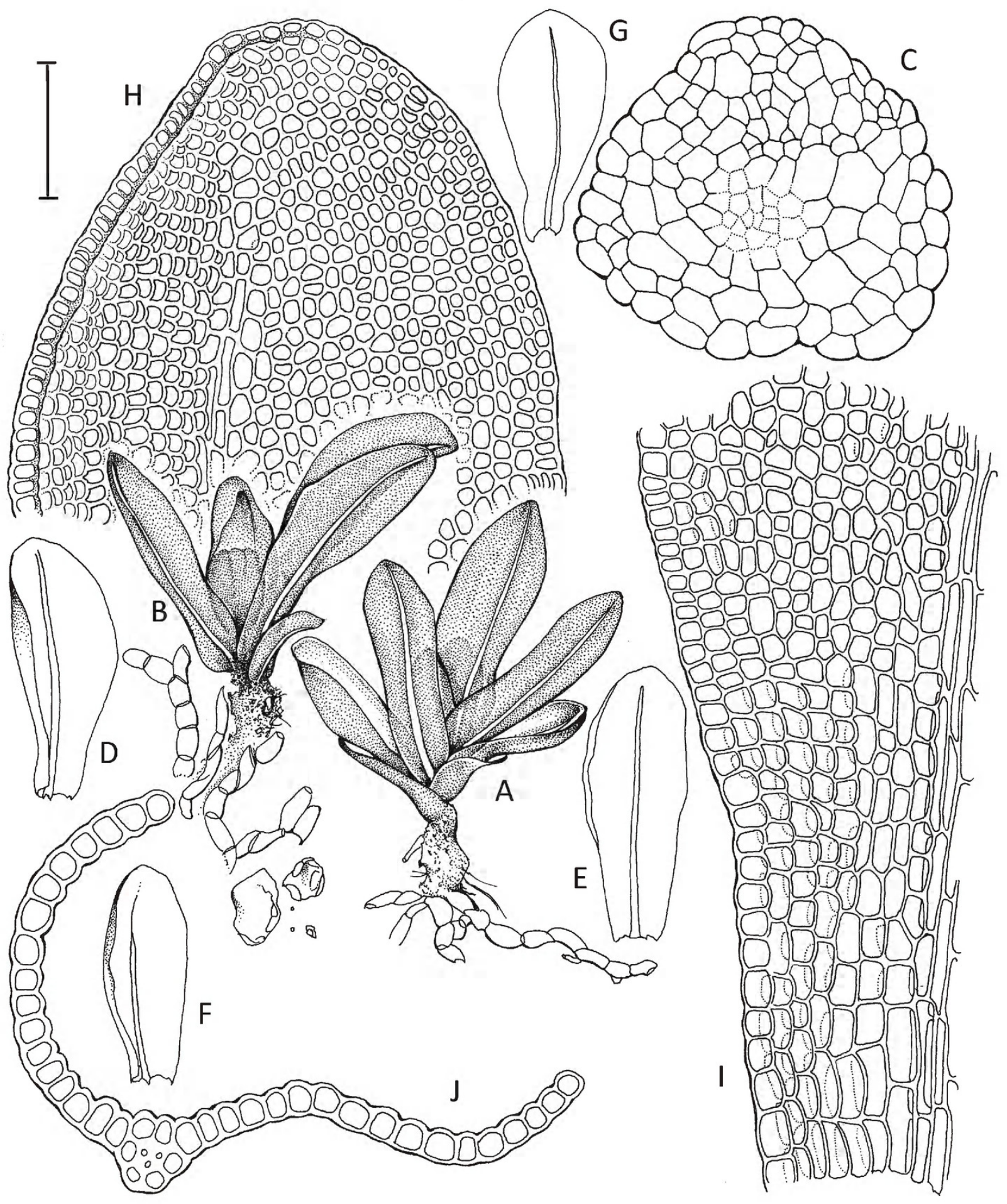

Fig. 1. Weisiopsis nigeriana, Australia, Streimann 39485 (MO). A, perichaetiate plant with perennating rhizoids; B, perigoniate plant with rhizoids; C, cross section of stem; D-G, leaves; H, leaf apex; I, leaf basal areolation; J, section of leaf at about mid-leaf. Scale bar: for A-B and D-G $=0.3 \mathrm{~mm}, \mathrm{C}, \mathrm{H}-\mathrm{J}=50 \mu \mathrm{m}$. 


\section{$2 \mathrm{BHL}$ Biodiversity Heritage Library}

Zander, Richard H. and Sollman, Philip. 2017. "Weisiopsis nigeriana

(Pottiaceae, Bryophyta) new to Australia, with perennating rhizoids." Telopea: Journal of plant systematics 20, 115-118. https://doi.org/10.7751/telopea11466.

View This Item Online: https://www.biodiversitylibrary.org/item/282222

DOI: https://doi.org/10.7751/telopea11466

Permalink: https://www.biodiversitylibrary.org/partpdf/305553

\section{Holding Institution}

The Royal Botanic Gardens and Domain Trust, New South Wales, Australia

\section{Sponsored by}

Atlas of Living Australia

\section{Copyright \& Reuse}

Copyright Status: In copyright. Digitized with the permission of the rights holder.

Rights Holder: The Royal Botanic Gardens and Domain Trust, New South Wales, Australia License: http://creativecommons.org/licenses/by-nc-sa/4.0/

Rights: http://biodiversitylibrary.org/permissions

This document was created from content at the Biodiversity Heritage Library, the world's largest open access digital library for biodiversity literature and archives. Visit BHL at https://www.biodiversitylibrary.org. 